\title{
Małgorzata H. Kowalczyk, Agnieszka Latoś, Żony, matki - zabójczynie. Studium zwiktymizowanej zbrodni, Wydawnictwo Naukowe Uniwersytetu Mikołaja Kopernika, Toruń 2016, ss. 464
}

Przyczyny przestępczości są różnorodne, począwszy od aspektów sytuacyjnych, czynów popełnianych pod wpływem lęku, w afekcie, a skończywszy na długotrwałych sytuacjach trudnych, które towarzyszą jednostce w jej życiu. Publikacja pt. Żony, matki-zabójczynie. Studium zwikymizowanej zbrodni jest pozycją, w której przestępczość przedstawiona została modelowo, w oparciu o zaburzone relacje interpersonalne, które zdeterminowały proces wiktymizacyjny, stanowiąc jednocześnie proces motywacyjny dokonanych zabójstw przez kobiety. Recenzowana pozycja charakteryzuje się interdyscyplinarnością, gdyż osadzona jest na pograniczu kilku obszarów, mianowicie kryminologii, wiktymologii, ale także pedagogiki resocjalizacyjnej, ze względu na uwzględnienie szerokiej gamy możliwości oddziaływań resocjalizacyjnych wobec sprawczyń zabójstw. Charakter interdyscyplinarny motywowany jest przez autorki specyfiką podjętej problematyki, szczególnej złożoności procesu, podczas którego kobiety z ofiar stają się sprawczyniami przemocy, bądź czynią je nimi wydarzenia życiowe.

Innowacyjny charakter analizy wyników badań polega m.in. na opracowanych trajektoriach życia kobiet, które zawierają punkty krytyczne odnoszące się do doświadczeń przemocowych, prowadzących w konsekwencji do popełnienia czynu przestępczego $\mathrm{z}$ art. $148 \mathrm{kk}$. Jednym $\mathrm{z}$ atutów recenzowanej publikacji jest odmienna perspektywa, z jakiej przeanalizowana została problematyka zabójstw dokonywanych przez kobiety. W dotychczasowych publikacjach z tego zakresu autorstwa m.in. Zdzisława Majchrzyka dominuje podejście psychologiczne (Motywacje zabójczyń. Alkohol i przemoc $w$ rodzinie, Warszawa 1995; Kiedy kobieta zabija. Motywy, osobowość, relacja sprawca-ofiara, strategie obronne, Warszawa 2009). W opracowaniu Motywacje zabójczyń Majchrzyk podkreśla, iż zabójstw dokonanych przez partnerki 
w rodzinach prokreacyjnych nie można rozpatrywać bez uwzględnienia doświadczeń przemocy w rodzinach naturalnych. W publikacji Kiedy kobieta zabija autor nie koncentruje się wyłącznie na wczesnodziecięcych doświadczeniach przemocy, podkreślając rolę wiktymizacyjnej relacji sprawca-ofiara, a także wyuczonych strategii adaptacyjno-obronnych. Dane dotyczące występowania przemocy w rodzinach generacyjnych zostały tylko zasygnalizowane, skupiono się przede wszystkim na transgeneracyjności przemocy w relacji ojciec agresor-syn agresor (2009, s. 256). Ważną pozycją poruszającą zagadnienie zabójstw konfrontacyjnych dokonywanych przez kobiety jest opracowanie Magdaleny Budyn-Kulik (Zabójstwo tyrana domowego: studium prawnokarne i wiktymologiczne, Lublin 2005). Natomiast zapowiedź rozwiniętych w recenzowanej monografii kwestii upatruję w artykule Małgorzaty H. Kowalczyk pt. Transgerencyjne wzory przemocy seksualnej w genezie zachowań kobiet wykorzystujacych seksualnie dzieci (który ukazał się w publikacji pod redakcją Kowalczyk i Michała Szykuta, Współczesne problemy resocjalizacji. W poszukiwaniu nowych rozwiqzań, Torun 2015). Jednak wyjątkowość recenzowanej monografii wynika z próby opisania zjawiska „zwiktymizowanej zbrodni" w szerokim kontekście nie tylko w odniesieniu do zabójstwa partnera życiowego, ale także dziecka. Problematyka zabójstw dzieci podejmowana jest w opracowaniach współautorki recenzowanej monografii, Agnieszki Latoś (Zabiłam własne dziecko... studium przypadków zabójczyń dzieci oraz możliwości ich resocjalizacji, Bydgoszcz 2012), oraz Krystyny Marzec - Holki (Dzieciobójstwo. Przestępstwo uprzywilejowane, czy zbrodnia, Bydgoszcz 2004).

Recenzowana publikacja składa się z wprowadzenia, ośmiu rozdziałów a także zestawienia bibliograficznego. Ilość rozdziałów uzasadniona jest obszernością i dualnym charakterem wybranej problematyki: zabójczynie mężów - zabójczynie dzieci. Dokonując merytorycznej oceny pracy o charakterze teoretyczno-empirycznym, ważne jest by podkreślić osadzenie teoretyczne problematyki badawczej. Autorki podkreśliły znaczenie integralnego spojrzenia na problematykę zabójstw, uwzględniając czynniki biologiczne, socjologiczne i psychologiczne, odwołując się do następujących teorii integracyjnych: teorii Harry'ego S. Sullivana, teorii GST Roberta Agnew oraz integracyjnej hipotezy trójstopniowego działania norm Adama Podgóreckiego. Opis wybranych teorii integracyjnych zawarty jest w pierwszym rozdziale monografii. Autorki dobrały koncepcje, które zawierają dwa, interesujące dla badaczek komponenty, mianowicie odczuwane napięcie a także jaźń odzwierciedloną, czyli samoocenę stanowiące predykatory zachowań przestępczych. Jak wskazuje Kowalczyk koncepcja Podgóreckiego pozwala 
na wyjaśnienie, dlaczego tylko część jednostek poddanych określonym czynnikom, dokonuje czynów dewiacyjnych, a inne szukają rozwiązań akceptowalnych społecznie (s. 39).

W rozdziale drugim Kowalczyk przedstawia specyfikę zabójstw dokonanych przez kobiety, prezentuje rys historyczny, uwzględniając pisma Starego Testamentu, czasy Cesarstwa Rzymskiego, zabójcze czyny kobiet w średniowieczu, a także zabójstwa dokonane przez kobiety w czasach współczesnych. W rozdziale scharakteryzowano studium wybranych przypadków. Autorka opisuje czynniki ryzyka powiązane z dokonywaniem zabójstw przez kobiety uwzględniając perspektywę interdyscyplinarną m.in. biologiczną, powołując się na klasyczne koncepcje cech atawistycznych Cesary'ego Lombrosa, psychologiczną Zygmunta Freuda czy szeroki kontekst społeczno - kulturowy, w którym autorka czynników ryzyka doszukuje się w procesie socjalizacji, m.in. w sposobie wypełniania ról społecznych, realizacji funkcji rodzin w szczególności ich dysfunkcjonalności i patologizacji (ze szczególnym uwzględnieniem stosowania przemocy). Ostatni omówiony aspekt dotyczy motywacji sprawczyń zabójstw. Autorka dokonuje rozróżnienia pojęć, a także wskazania właściwych, zastępując termin motywacji pojęciem procesu motywacyjnego i tła motywacyjnego czynu. Przywołuje w tej części typologie i klasyfikacje motywów zabójstw na podstawie literatury przedmiotu.

Rozdział trzeci opracowany został przez Latoś. Zaprezentowano w nim problematykę przemocy w rodzinie, uwzględniając w szczególności przemoc stosowaną wobec dziecka. Autorka operacjonalizuje pojęcia, ukazuje perspektywy interpretacji problemu, wyodrębnia kategorie, charakteryzując relacje sprawca - ofiara. Prezentuje także cykl i rodzaje przemocy. Istotne wydaje się w tym miejscu podkreślenie formy przemocy, jaką jest „zaniedbywanie” określanej przez autorkę jako „specyficzna forma przemocy stosowaną wobec dziecka, należącą do jej biernych postaci i jako taka nie polegająca na użyciu siły. Istotą zaniedbywania jest bowiem powstrzymanie się od działania, a nie samo działanie" (s. 101). Zaniedbanie dziecka jest zjawiskiem słabo opisanym w literaturze, a zatem słabo przebadanym, podkreślenie roli owej formy przemocy jest szczególnie istotne dla wychowawców, a pełne zrozumienie zjawiska pozwoliłoby na szybszą jego diagnozę i konstruowanie projektów profilaktycznych przeciwdziałających temu problemowi. Latoś opisała jeszcze jedno kontrowersyjne zjawisko, jakim jest przemoc wobec dziecka nienarodzonego po 12 tygodnia ciąży, a także długofalowe skutki, które wywołuje ta forma przemocy. Charakter konsekwencji stosowania przemocy także oscyluje wokół zainteresowań badaczki, która wskazuje przede wszystkim skutki o charakterze psychologicznym, m.in.: mecha- 
nizm błędnego koła, proces wiktymizacji i syndrom sztokholmski. Kolejne elementy opisane przez autorkę to sposoby dokonania zabójstw dzieci, profil potencjalnej sprawczyni a także prezentacja sposobów doprowadzenia dziecka do śmierci, m.in. zespół Münchenhausena i zespół dziecka potrząsanego. Autorka sięgnęła tutaj po literaturę z zakresu medycyny. Motywy zbrodni Latoś opisuje, odwołując się do wyników badań innych autorów.

Osobny rozdział poświęcono analizie literatury przedmiotu dotyczącej żon, partnerek jako sprawczyń zabójstw domowych. Autorka tego rozdziału, Kowalczyk, koncentruje się na wyjaśnieniu mechanizmu stawania się ofiarą, omawia konsekwencje psychologiczne, skupiając największą uwagę na opisie syndromu wyuczonej bezradności, syndromie bitej kobiety czy kompleksie PTSD. Opracowuje portret psychologiczny, tzw. profil potencjalnej sprawczyni zabójstw, a także charakteryzuje relacje sprawca-ofiara wskazując, na najczęściej występujące strategie adaptacyjne do sytuacji przemocowej.

Rozdział piąty to założenia metodologiczne przyjęte $\mathrm{w}$ badaniach. Autorki na początku rozdziału podkreślają złożoność tematu, wskazując na element wspólny dokonanych zbrodni, jakim jest przemoc definiowana jako „kategoria doświadczeń traumatycznych, z którymi miały do czynienia badane sprawczynie i które spowodowały uruchomienie nieadekwatnych mechanizmów obronnych, utrwalenie wzorców przemocowych, sprzyjających procesowi wiktymizacji" (s. 199). Badaczki usytuowały problem w paradygmacie woluntarystycznym i interpretatywnym. Wybór uwzględnia oczekiwania autorek, które zainteresowane są poznaniem m.in. stanów emocjonalnych czy motywacyjnych. Badaczki przyjęły model indukcyjny charakterystyczny dla badań jakościowych. Celem badań jest „opis i interpretacja sytuacji życiowej badanych sprawczyń zabójstw a w szczególności zaprezentowanie i wyjaśnienie skutków doświadczeń wychowawczych i relacji z innymi osobami, które to relacje mogą stać się źródłem procesu wiktymizacji i wyboru nieadekwatnych sposobów radzenia sobie z sytuacjami napięcia motywacyjnego" (s. 201-202). Autorki posłużyły się metodami wywiadu i przeszukiwania źródeł wtórnych, dokonały doboru próby w sposób nielosowy. W części metodologicznej opisały procedurę przystąpienia do badań, a także poszczególne etapy analizy uzyskanych danych jakościowych (s. 203-217).

Rozdział szósty to pierwsza część analizy uzyskanego materiału badawczego dotyczącego sprawczyń zabójstw partnerów autorstwa Kowalczyk. Materiał uporządkowany został przy wykorzystaniu matryc oraz mapy sieci przyczynowych. Autorka wyodrębniła dwie matryce: pierwszą stanowiącą listę kontrolną, obejmującą rodzinę generacyjną i prokreacyjną, 
doświadczenie przemocy, przejawy wiktymizacji i mechanizmy obronne. Druga z matryc jest zorientowana na relacje obejmujące stosunki z matką, ojcem, rodzeństwem, partnerem i dzieckiem bądź dziećmi. Autorka zaprezentowane dane, które dzięki pojęciowemu uporządkowaniu są klarowne dla czytelnika, poddała pogłębionej analizie i interpretacji. Wyniki wskazują na wspólne dla badanych negatywne cechy rodzin pochodzenia, które wpłynęły na internalizację wzorów zachowań w relacji mężczyzna-kobieta i wzorów funkcjonowania rodziny. Kolejnym aspektem analizowanym przez autorkę była sytuacja w związkach badanych kobiet, a także występujące w nich przejawy patologii. Wyniki badań $\mathrm{w}$ niniejszym kontekście potwierdzają transgeneracyjne powielanie wzorców zachowań zinternalizowanych w środowisku rodzin pochodzenia, co uwidacznia się w szczególności w wyborze partnera bez względu na występujące symptomy zachowań patologicznych. Trwanie w tych związkach, brak podjęcia walki z własną sytuacją określone jest przez badaczkę jako „zaawansowany proces wiktymizacji” (s. 259). W kolejnym podrozdziale autorka charakteryzuje wzajemne relacje z członkami rodzin i partnerami. Zauważa potrzebę ustalenia charakteru relacji, który wynika z przyjętej podstawy teoretycznej Harrego Sullivana, traktującego zaburzenia psychiczne jako niewłaściwe relacje interpersonalne czy wynik presji społecznej. Analiza relacji w rodzinie naturalnej i prokreacyjnej pozwoliła opracować noty teoretyczne dla każdej z badanych, w których Kowalczyk ukazuje proces „przeniesienia” zachowań i postaw prezentowanych w rodzinach generacyjnych na rodziny tworzone w wieku dorosłym. Autorka zobrazowała ten proces używając sieci relacji. Najistotniejszą częścią dokonanej analizy jest prezentacja procesu wiktymizacyjnego każdej z badanych sprawczyń. Autorka wskazała jeszcze na współwystępujące symptomy wyuczonej bezradności, oznaki psychologicznej pułapki, w jaką wpadły badane, a także mechanizm błędnego koła. Rozdział zamyka prezentacja graficzna sieci przyczynowej przypadku, która ukazuje proces holistycznie, począwszy od funkcjonowania badanych w rodzinie pierwotnej aż do mechanizmu popełnienia zbrodni (s. 317-325). Użycie matryc jest niewątpliwym atutem, a także zabiegiem grupującym i uszczegóławiającym, jednak w tym przypadku wielość matryc, a także kolejne dodatkowe elementy spowodowały częściowe powtarzanie się informacji, a rozczłonkowanie materiału utrudniło analizę konkretnych przypadków, niezbędne było tu wracanie do tekstu umieszczonego kilkanaście stron wcześniej. Dodatkową trudność sprawiło porównywanie przypadków (danych w matrycach), ze względu na wielkość matryc a także obszerność treści w nich umieszczonych. 
W rozdziale siódmym, Latoś dokonuje analizy i interpretacji zabójstw dokonanych przez matki na dzieciach. Schemat analizy jest tożsamy z wersją Kowalczyk, autorka dodatkowo w opisie sytuacji życiowej badanych sprawczyń powołuje się na badania innych autorów, które stanowią potwierdzenie uzyskanych wyników. Autorka przebadała cztery kobiety skazane z art. 148 kk, będące sprawczyniami zabójstw własnych dzieci. Analiza wybranych przypadków jest spójna, jednak opis przypadku trzeciego zawiera błędy informacyjne. W opisie przypadku autorka podaje: „po porodzie zawinęła je w reklamówkę, czym spowodowała jego uduszenie" (s. 410), w nocie teoretycznej znajdują się następujące informacje: „skazana doprowadziła do śmierci swojego dziecka poprzez okręcenie mu szyi pępowiną, czym spowodowała jego uduszenie" (s.412). Te dwa opisy prezentują zupełnie inny charakter modus opernadi.

Zapoznanie się z rozdziałem siódmym szczególnie polecam pedagogom penitencjarnym, pracownikom socjalnym, kuratorom, gdyż pogłębiona analiza sytuacji życiowej badanych i praca na wielu źródłach pozwoliła wyodrębnić czynniki ryzyka popełnienia zabójstwa i ustalić proces postępowania resocjalizacyjnego.

Ocenie publikacji podlega realizacja celu jaki założyły badaczki, jasność przekazu, adekwatność wybranych teorii do problemów, rzetelność dokonanej analizy a także dbałość o estetykę w edycji tekstu. Niewątpliwie autorki zrealizowały cel badań, ukazały proces wiktymizacji, czyli proces wchodzenia w rolę ofiary, następnie przeanalizowały proces transgeneracji destruktywnych wzorów zachowań z rodzin pochodzenia na rodziny prokreacyjne. Wybór zaplecza teoretycznego jest spójny, opiera się na analizie jakościowej. Badaczki ukazały proces powstawania napięcia motywacyjnego i strategii radzenia sobie w sytuacjach, w których ostatecznością było rozładowanie napięcia poprzez dokonanie zbrodni. Uznanie budzi zarówno pogłębiona analiza materiału badawczego, jak i operowanie pojęciami psychologicznymi, których znajomość bez wątpienia była istotna w przypadku badania kobiet. Kolejnym atutem książki jest język, autorki operowały językiem specjalistycznym, jednak każde wprowadzane pojęcie operacjonalizowały, dlatego pozycja ta staje się przystępna dla czytelnika. Pod względem edytorskim wystąpiło kilka błędów literowych i pomyłka w nazwie rozdziału 7.5 „Zabójstwo partnera życiowego - tło motywacyjne i sytuacyjne", który dotyczy zabójstw dzieci. Nieliczne błędy, głównie edytorskie nie wpływają na ocenę publikacji. Uważam, że jest cenną i innowacyjną pozycją a także najnowszą propozycją specjalistyczną z obszaru kryminologiczno-wiktymologicznego. 
Książka może stać się inspiracją dla organizacji i instytucji przeciwdziałających przemocy w rodzinie, dla wychowawców więziennych może być źródłem informacji w zakresie diagnozowana i programowania oddziaływań penitencjarnych, natomiast z poznawczego punktu widzenia dla studentów i młodych badaczy może stanowić inspirację i pomoc w konstruowaniu założeń metodologicznych w badaniach jakościowych. Precyzyjna analiza i dbałość o każdy szczegół, a także dokładny proceduralny opis ukazuje doświadczenie autorek i bogaty warsztat pracy metodologicznej.

Anita Kotlenga 